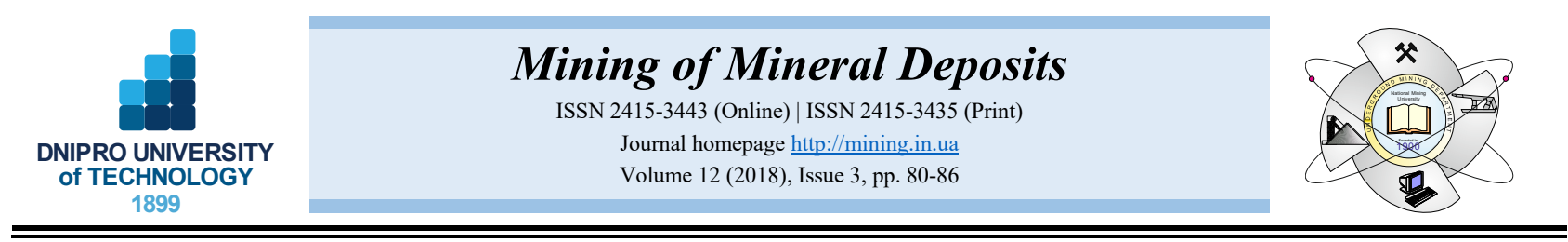

UDC 622.7 .01

https://doi.org/10.15407/mining12.03.080

\title{
ENERGY CONSUMPTION ANALYSIS FOR NATURAL AGGREGATE PROCESSING AND ITS RESULTS (ATABEY, ISPARTA, TURKEY)
}

\author{
M. Ozcelik ${ }^{1 *}$ \\ ${ }^{1}$ Süleyman Demirel University, Isparta, Turkey \\ *Corresponding author: e-mail ozcelikmehmet@sdu.edu.tr, tel. +902462111327
}

\begin{abstract}
Purpose. This study was conducted to determine the amount of energy and water consumption in the production of aggregates for a certain period of time and also calculated the parameters that effect energy consumption in natural aggregate processing.
\end{abstract}

Methods. The data obtained from the quarry site were used as a case study which is presented in the paper. It was discovered that during the winter season, less production and processing activities consume more electrical energy and less water.

Findings. Energy consumption ratios for 5 years are presented in the paper with the calculated mean at $4.44 \mathrm{kWh}$. However, the energy consumed during the experimental study on the site was calculated to be $2.69 \mathrm{kWh}$. Additionally, benchmarking analysis was conducted on 4 different quarries for evaluation of energy consumption.

Originality. This study suggests that environmental load decrease be investigated with respect to quarry processing as well as equipment, technology and use. The result of the study reveals that processing technology implemented in the plant was not economically viable.

Practical implications. Two years after completion of the present study, processing at the quarry was stopped in 2015 .

Keywords: energy; energy consumption; benchmarking analysis; aggregate processing

\section{INTRODUCTION}

Aggregate materials are extensively used for all kinds of construction applications and infrastructure development and are essential for every modern economy (Galetakis, Zourbakis, Koinakis, Leventakis, \& Alevizos, 2013; Ismail, Hoe, \& Ramli, 2013). The most common natural aggregates of mineral origin are sand, gravel and crushed rock. Natural aggregate is the most ubiquitous construction material and is used in buildings, readymixed and precast concrete production, road paving, asphalt production, railroad ballast, mortar production, harbour construction and maintenance, cement and lime production (Wilburn \& Goonan, 1998; Gonçalves, Tavares, Toledo Filho, Fairbairn, \& Cunha, 2007).

Higher quality aggregate is required to have particles with adequate strength and good resistance to exposure conditions. Geological properties of the material will affect its performance regardless of the place an aggregate is used. Variability in the geology may affect sizing, and usually effects mineral composition, physical and mechanical properties. Some products may require separation at later stages in the processing; should large variation exist. Crushing, abrasion, volume change and chemical decom- position all are affected by changes in aggregate mineralogy and texture. Harthi \& Abo Saada (1997), Erdoğan, Eren, \& Oktay (1999), Yildırım \& Yilmaz (2002), Guimaraes, Valdes, Palomino, \& Santamarina, (2007), Scott \& Harrison (2008) have carried out detailed studies on the influence of various geological factors on aggregate properties. A quarry site can have various impacts on the environment as a result of operations performed during raw material transformation. These impacts are directly related to electrical energy consumption, emission released into air and water, and waste production (Faleschini, Zanini, Pellegrino, \& Pasinato, 2016). All of these are known to contribute to global environmental loads (Menegaki \& Kaliampakos, 2010; Jullien, Proust, Martaud, Rayssac, \& Ropert, 2012). Mining is known as an energy intensive industrial sector (Awuah-Offei, 2016) and is identified by the US Department of Energy as energy intensive (Kaarsberg, HuangFu, \& Roop, 2007). At the same time, the mining sector could significantly improve its energy efficiency. This is evident from the correlation between increased interest in energy efficiency and energy prices (Kecojevic, Vukotic, \& Komljenovic, 2014; Levesque, Millar, \& Paraszczak, 2014). 
Additionally, natural aggregates are heavy items. It is commonly known that beyond a certain distance range, the energy (and financial) cost of material transportation far outweighs the production energy (Blachowski, 2013). This is important for two reasons. The first is that it explains the abundance of aggregate producing quarries spread across the whole of Turkey. The second is that availability of the appropriate material is determined by the geological structure, while accessibility of materials is often limited by planning constraints.

Energy and water consumption from aggregates production was investigated in this study at a quarry site. The benchmarking analysis conducted on the basis of data from 4 different quarries evaluated energy consumption. It increases during the winter season, and it is estimated that two times more energy is spent on production during the winter. It can be concluded that a very high percentage of electrical energy is consumed during the winter (December, January and February) season. On the other hand, according to the analysis, less water is consumed for production.

\section{MATERIAL AND METHODS}

As far as possible, the analysis in this paper has been based on actual measurements of energy use, rather than results from previous studies and generic data. The production cycle has been analysed and the energy demand of the various stages has been calculated on the basis of the input electricity.

\subsection{Description of the site}

The study area, Atabey aggregate quarry, covers approximately the size of 3.8694 hectares. The quarry is located about $27 \mathrm{~km}$ away from Isparta city. Most of the sand and gravel is produced from alluvial deposits located along the Akçay Basin, which consists mainly of mudstone, sandstone, and pebblestone alternations (Fig. 1).

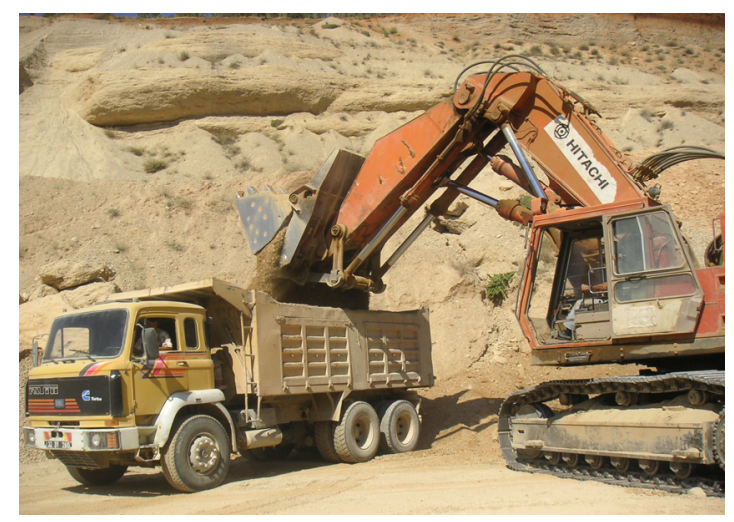

Figure 1. View of the site at the extraction stage

\subsection{Data collection}

Aggregates are valuable raw materials. To make the best use of deposits, equipment must be tailored to the particular situation and requirements. Benefits include precisely customised end products, low water and energy consumption, minimal sand loss, user-friendly operation and low maintenance costs.

\subsection{Calculation of crushing-screening plant energy use}

Aggregate fractions with various size distributions were considered; i.e. three different crusher settings, high, normal and low, were studied. Moreover, this parameter study was reproduced in three different selected locations at the Atabey aggregate quarry. Aggregate materials were transported from the quarry to the screening-processing plant by truck. Four different types of aggregate were produced and cheaply transported to their ready markets. The dominant material types are sand, pebble and cobble gravels. The grains were separated according to their different sizes: primary $(0-7 \mathrm{~mm})$, secondary $(7-15 \mathrm{~mm})$, tertiary $(15-25 \mathrm{~mm})$, coarse gravel for re-crush $(25-35 \mathrm{~mm})$ size fractions in the crushing-screening plant (Fig. 2). 91.31\% of the materials taken from the quarry were made ready for use after processing in crushing-screening plant.

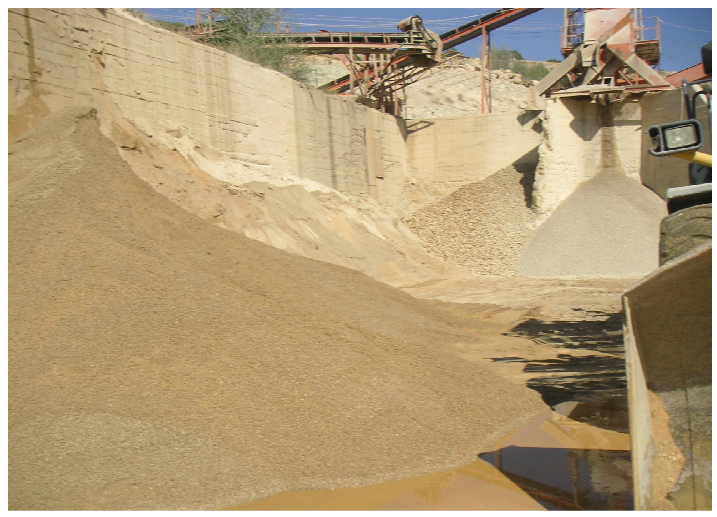

Figure 2. End product of aggregate materials in the production process

Wheeled and tracked loaders are used for loading materials at the quarry. The natural aggregates taken from the three selected quarries were transported by four trucks for processing. The materials and trucks were weighed with a bunker, and the truck was weighed again after emptying its content to get the net weight (Table 1).

Table 1. Natural aggregate taken from quarry

\begin{tabular}{cccc}
\hline Quarry No. & $\begin{array}{c}\text { Truck weight, } \\
\mathrm{kg}+\text { product }(\mathrm{kg})\end{array}$ & $\begin{array}{c}\text { Truck } \\
\text { weight, } \mathrm{kg}\end{array}$ & $\begin{array}{c}\text { Product, } \\
\mathrm{kg}\end{array}$ \\
\hline \multirow{3}{*}{ Quarry 1 } & 41620 & 13020 & 28600 \\
& 41660 & 13360 & 28300 \\
& 41660 & 14400 & 27260 \\
Quarry 2 & 35340 & 13040 & 22300 \\
& 39880 & 13360 & 26520 \\
& 32020 & 14400 & 17620 \\
Quarry 3 & 40180 & 13020 & 27160 \\
& 35860 & 13040 & 22820 \\
\hline & 45360 & 13020 & 32340 \\
& 44820 & 13040 & 31780 \\
& 46300 & 14400 & 31900 \\
& 42600 & 13360 & 29240 \\
\hline
\end{tabular}

The first step of processing begins after extraction of the material from the quarry. Many of these steps are also common in processing of recycled materials, clay, and 
other manufactured aggregates (Rosado, Vitale, Penteado, \& Arena, 2017).

The first stage in most operations is reduction and sizing by crushing. Crushing most often is used to divert fine grains at a jaw primary crusher in order to improve crusher efficiency. In this way, the coarsest portion is crushed and then recombined with the portion of crusherrun material before further processing. Secondary and tertiary crushing are the final steps in reducing the material to a desired product size. The results of material processing are given in Table 2 .

Table 2. End products from crushing-screening plant

\begin{tabular}{|c|c|c|c|}
\hline Product & $\begin{array}{l}\text { Truck weight, } \\
\mathrm{kg}+\text { product, } \mathrm{kg}\end{array}$ & $\begin{array}{c}\text { Truck } \\
\text { weight, kg }\end{array}$ & $\begin{array}{l}\text { Product, } \\
\text { kg }\end{array}$ \\
\hline \multirow{5}{*}{$\begin{array}{c}\text { Primary } \\
\text { gravel } \\
(0-7 \mathrm{~mm})\end{array}$} & 45740 & 13360 & 32380 \\
\hline & 57720 & 17400 & 40320 \\
\hline & 54940 & 16100 & 38840 \\
\hline & 46320 & 14400 & 31920 \\
\hline & 43780 & 13020 & 30760 \\
\hline $\begin{array}{c}\text { Secondary } \\
\text { gravel } \\
(7-15 \mathrm{~mm})\end{array}$ & 40020 & 13020 & 27000 \\
\hline $\begin{array}{c}\text { Tertiary } \\
\text { gravel } \\
(15-25 \mathrm{~mm})\end{array}$ & 46680 & 16100 & 35580 \\
\hline Coarse gravel & 43660 & 17400 & 26260 \\
\hline $\begin{array}{l}\text { for re-crush } \\
(25-35 \mathrm{~mm})\end{array}$ & 48880 & 14400 & 34480 \\
\hline
\end{tabular}

According to Table 2:

- primary gravel product $\left(A P_{1}=174220 \mathrm{~kg}\right)$;

- secondary gravel $\left(A P_{2}=27000 \mathrm{~kg}\right)$;

- tertiary gravel $\left(A P_{3}=34580 \mathrm{~kg}\right)$;

- coarse gravel $\left(A P_{4}=60740 \mathrm{~kg}\right)$.

$\sum A P=A P_{1}+A P_{2}+A P_{3}+A P_{4}=297540 \mathrm{~kg}$.

Coarse gravel after the re-crush processing is shown in Table 3.

Table 3. End products from re-crush

\begin{tabular}{|c|c|c|c|c|}
\hline \multicolumn{2}{|c|}{ Product } & $\begin{array}{c}\text { Truck } \\
\text { weight, } \\
\mathrm{kg}+\text { product, } \\
\mathrm{kg}\end{array}$ & $\begin{array}{l}\text { Truck } \\
\text { weight, } \\
\text { kg }\end{array}$ & $\begin{array}{l}\text { Product, } \\
\mathrm{kg}\end{array}$ \\
\hline \multirow{2}{*}{\multicolumn{2}{|c|}{$\begin{array}{l}\text { Coarse gravel } \\
\text { for re-crush } \\
(25-35 \mathrm{~mm})\end{array}$}} & 33940 & 14400 & 19540 \\
\hline & & 33180 & 13360 & 19820 \\
\hline \multirow{3}{*}{ 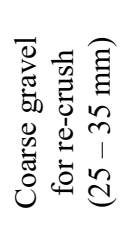 } & $\begin{array}{l}\text { Primary } \\
\text { product }\end{array}$ & 24700 & 13360 & 11340 \\
\hline & $\begin{array}{l}\text { Secondary } \\
\text { product }\end{array}$ & 33120 & 13040 & 20080 \\
\hline & $\begin{array}{l}\text { Secondary } \\
\text { product }\end{array}$ & 28420 & 13020 & 15400 \\
\hline
\end{tabular}

\subsection{Water consumption}

Water is critical for quarrying and mining (for cooling, crushing, grinding, milling ore, slurry transportation and tailings storage). So, it is important to consider any climate-related impacts on the quality and availability of water resources with implications for efficiency and cost. Washing and sorting aggregates are water-intensive processes.
Considerable amount of water is lost during evaporation and incorporation into the product. Emplo-ying water efficiency practices reduces water loss and saves money, protecting surface and groundwater supplies. Water consumption at the Atabey aggregate quarry is given in Table 4.

Table 4. Water consumption at the Atabey aggregate quarry

\begin{tabular}{lcccc}
\hline Month & $\begin{array}{c}\text { Cleaning } \\
\text { of equip- } \\
\text { ment, } \mathrm{m}^{3}\end{array}$ & $\begin{array}{c}\text { Sprink- } \\
\text { ling, } \mathrm{m}^{3}\end{array}$ & $\begin{array}{c}\text { Water con- } \\
\text { sumed for } \\
\text { crushing- } \\
\text { screening } \\
\text { plant, } \mathrm{m}^{3}\end{array}$ & $\begin{array}{c}\text { Water } \\
\text { consumed } \\
\text { monthly, } \mathrm{m}^{3}\end{array}$ \\
\hline January & 5 & 10 & 20 & 875 \\
February & 5 & 10 & 20 & 875 \\
March & 5 & 10 & 20 & 875 \\
April & 5 & 10 & 20 & 875 \\
May & 5 & 15 & 30 & 1000 \\
June & 5 & 15 & 30 & 1000 \\
July & 5 & 15 & 30 & 1000 \\
August & 5 & 15 & 30 & 1000 \\
September & 5 & 15 & 30 & 1000 \\
October & 5 & 15 & 30 & 1000 \\
November & 5 & 10 & 20 & 875 \\
December & 5 & 10 & 20 & 875 \\
\hline
\end{tabular}

\subsection{Energy consumption}

The total energy consumption comprises processing and crushing-screening. For energy consumption, two sets of parameters appear to be essential: actual consumption of the various electrical motors and material flows crossing the processing plant. The first can be obtained by direct measurement using a tachometer. The method chosen to calculate energy consumed per ton of produced aggregate consists in summing the hour of consumption at various crushing-screening plants.

Energy consumption is important for all the 3 stations and internal transport (involving the use of conveyor belts and vehicles) between the extraction area and the treatment plant or washing plant. In order to write the equations describing electrical energy consumption for each piece of equipment, two types of data are essential: the actual electrical energy consumed by each machine, and the quantities of material processed through these machines (Jullien, Proust, Martaud, Rayssac, \& Ropert, 2012). The latter is managed in the model via the production line concept, which relates to a certain number of machines constituting a path and yielding the material with known particle grading. Each machine can then be linked with one or more production lines. Once the production lines have been defined, the amount of materials processed through each machine is determined.

The mass per production line is obtained by starting from the owner's production parameters. The specific electrical energy consumption of each machine can therefore be calculated by evaluating the consumption of the considered machine per material quantity passing through it on an hourly basis. The average power used by these machines is determined from both the operating periods and active electrical energy at the plant. For production purposes, aggregates are transported from the sample location by trucks. 
The calculation below is related to the energy consumed per one hour of production at the quarry site $\sum A P=A P_{1}+A P_{2}+A P_{3}+A P_{4}=297540 \mathrm{~kg}$ of aggregate was processed. Mean unit weight is $V=17.0 \mathrm{~N} / \mathrm{m}^{3}$.

Energy consumption: $E C_{1}=465 \mathrm{kWh}$ (for processing).

Energy consumption: $E C_{2}=6 \mathrm{kWh}$ (for screen-plant washing).

$$
\begin{aligned}
& M_{1}=\sum \frac{A P}{V}=\frac{297540}{1700}=175.023 \mathrm{~m}^{3} ; \\
& \sum E C_{A}=E C_{1}+E C_{2}=465+6=471 \mathrm{kWh} ; \\
& E_{A}=\frac{\sum E C_{A}}{M_{1}}=\frac{471}{175.023}=2.69 \mathrm{kWh},
\end{aligned}
$$

where:

$\Sigma A P$ - aggregate processed, $\mathrm{kg}$;

$M_{1}$ - aggregate production output, $\mathrm{m}^{3}$;

$E C_{1}$ - energy consumed for processing, $\mathrm{kWh}$;

$E C_{2}$ - energy consumed for crushing-screening plant washing, kWh;

$\Sigma E C_{A}$ - energy consumed;

$E_{A}$ - energy consumed per $\mathrm{m}^{3}$ of aggregate.

After re-crushing $(25-35 \mathrm{~mm})$, one hour of production $\sum B P=P_{p}+S_{p}+T_{p}=46820 \mathrm{~kg}$ of aggregate was processed.

Mean unit weight is $V=17.0 \mathrm{~N} / \mathrm{m}^{3}$.

Energy consumption: $E C_{3}=93 \mathrm{kWh}$ (for crushing).

Energy consumption: $E C_{4}=6 \mathrm{kWh}$ (for crushingscreening plant washing).

$$
\begin{aligned}
& M_{2}=\sum \frac{B P}{V}=\frac{46820}{1700}=27.541 \mathrm{~m}^{3} ; \\
& \sum E C_{B}=E C_{3}+E C_{4}=93+6=99 \mathrm{kWh} ; \\
& E_{B}=\frac{\sum E C_{B}}{M_{2}}=\frac{99}{27.541}=3.59 \mathrm{kWh},
\end{aligned}
$$

where:

$P_{p}$-primary product after re-crushing for coarse gravel;

$S_{p}$ - secondary product;

$T_{p}$ - tertiary product;

$\Sigma B P$ - aggregate processed, $\mathrm{kg}$;

$M$ - aggregate production output, $\mathrm{m}^{3}$;

$E C_{3}$ - energy consumed for processing;

$E C_{4}$ - energy consumed for crushing-screening plant washing;

$\Sigma E C_{B}$ - energy consumed;

$E_{B}$ - energy consumed per $\mathrm{m}^{3}$ of aggregate.

Energy consumption per $\mathrm{m}^{3}$ aggregate is $E_{A}=2.69$ $\mathrm{kWh}$ and $E_{B}=3.59 \mathrm{kWh}$. The mean energy consumption during crushing-screening and re-crushing for one hour is $3.14 \mathrm{kWh}$. This value was calculated and indicated in the equations (Equation 4 and 7).

Aggregates production improvement from environmental viewpoint is strongly dependent on the site equipment technology, homogeneity of gravels, grain size, climatic seasons, site organization and site geogra- phy (distances between extraction and plant). The geological site condition directly affects the energy consumption. Site characteristics should be investigated for screening-crushing processing and equipment performances. Finally, one of the purposes of this paper was to distinguish between crushed and round aggregates as they are done. At present, the collected site data do not really give room for that, however importance of grading is one of the main findings done in this study. Energy consumption was calculated for a 5-year period for $1 \mathrm{~m}^{3}$ aggregate production. During the examination, crushing and screening plant cleaning were done for 15 minutes, consuming about $6 \mathrm{kWh}$ of energy. The plant has three crushing and screening units that totally consume about $20 \mathrm{kWh}$ of energy.

According to the production year and months, energy consumed per unit of aggregate produced was calculated with the monthly energy consumption as shown in Figure 3.

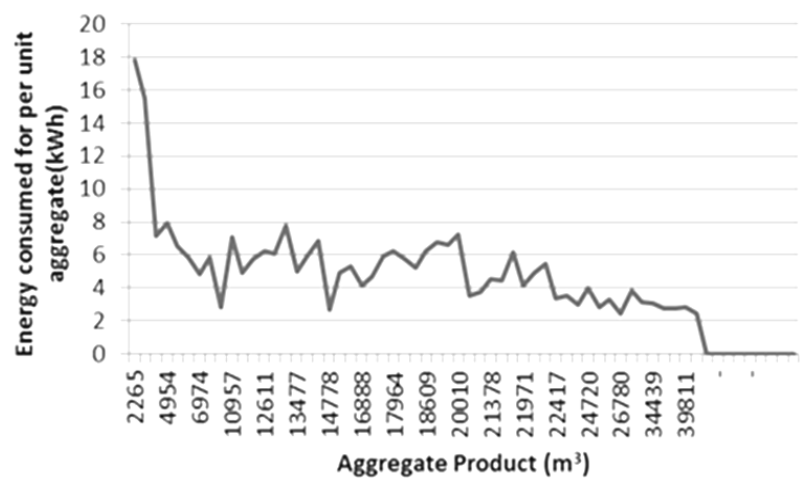

Figure 3. Relationship between aggregate end-products and energy used

In addition, energy consumption in the aggregate production during a five-year period is given in Table 5. Consequently, relationship between aggregate end-products and the energy consumption is shown in Figure 3.

Table 5. Energy used in processing aggregate (five-year period)

\begin{tabular}{lcccc}
\hline Year & $\begin{array}{c}\text { Aggregate } \\
\text { product, } \\
\mathrm{m}^{3}\end{array}$ & $\begin{array}{c}\text { Aggregate } \\
\text { product, t }\end{array}$ & $\begin{array}{c}\text { Energy } \\
\text { consumption, } \\
\mathrm{kWh}\end{array}$ & $\begin{array}{c}\text { Energy } \\
\text { consumption, } \\
\mathrm{kWh} / \mathrm{t}\end{array}$ \\
\hline First & 124173 & 211094.1 & 502660 & 2.38 \\
Second & 309212 & 525660.4 & 982779 & 1.86 \\
Tertiary & 217819 & 370292.3 & 853500 & 2.30 \\
Fourth & 183246 & 311518.2 & 1088140 & 3.49 \\
Fifth & 168167 & 285883.9 & 1023200 & 3.57 \\
\hline
\end{tabular}

This study has calculated the energy used for extraction and transportation of natural aggregates (sand and gravel) from the Atabey Quarry, and compared the figures related to the energy used in excavating and processing natural aggregates (sand, gravel and crushed rock) on land. The processing period analyzed was 5-year long, and the energy used was broken down into different phases of aggregate production, as shown in the graph (Fig. 3).

As seen in the graph (Fig. 3), energy consumption increased during the winter season. On the contrary, water consumption decreased during the winter (Table 4). While the amount of processed materials decreased, energy consumption increased for that season. 


\section{ADVANCES IN TECHNOLOGY}

In order to meet final requirements, it is essential to incorporate the knowledge about proportioning and use of materials in production technology which combines various equipment and methodologies to transform geological material into construction material (Pérez Fortes, Anastasio, Kuznetsova, \& Danielsen, 2016). Mining depends heavily on machinery for almost every aspect of the process, from initial extraction to transportation, and to final processing. Overall increase in productivity requires improvement in machine performance, operation efficiency and reduction of maintenance costs. Machine performance can be improved by development and application of better maintenance strategies.

\subsection{Comparison of energy consumption in similar quarries}

Quarry locations differ greatly, so geological environment may dictate great differences in the amount of energy required for extraction of a similar product. The differences among sites cause problems when trying to use a benchmarking approach to energy consumption. To be used effectively, benchmarking requires a detailed understanding of the differences among sites which allows to realistically identify the scope of potential improvements. There is a great deal of interaction among the energy requirements for different operational stages in a quarry. These may not always be obvious. Therefore, optimization through minimizing the energy required for any single process may not result in reduction of the overall energy used for processing. A holistic approach is required when considering any changes. There are many schemes and technologies that may deliver improvements to energy efficiency in the quarry environment. Differences in the sites cause problems when trying to benchmark energy usage. This is true for a quarry as a whole and also for most of the individual processing steps within the quarry operation. The best opportunities may arise with quarry operations that may be considered similar to each other. Benchmark case studies were analyzed for energy consumption at four quarries. Four different quarry data about energy consumption at the processing plant are provided in Table 6 . These are averaged energy values in $\mathrm{kWh}$ per ton (cubic meter) of product.

Table 6. Monthly energy consumption by crushers at different quarries

\begin{tabular}{lcccc}
\hline \multirow{2}{*}{ Month } & \multicolumn{4}{c}{ Energy consumption, kWh/t } \\
\cline { 2 - 5 } & $\begin{array}{c}\text { NETAS } \\
\text { limestone } \\
\text { quarry } \\
\text { (Netas, }\end{array}$ & $\begin{array}{c}\text { KOSK } \\
\text { limestone } \\
\text { quarry } \\
\text { (Kosk, }\end{array}$ & $\begin{array}{c}\text { Upper Aravadi } \\
\text { limestone } \\
\text { quarry } \\
\text { (Tosun \& }\end{array}$ & $\begin{array}{c}\text { This } \\
\text { study } \\
\text { site }\end{array}$ \\
\hline January & 0.89 & 1.23 & 1.636 & - \\
February & 0.76 & 1.50 & 1.866 & 10.46 \\
March & 0.68 & 1.72 & 1.756 & 3.42 \\
April & 0.75 & 1.29 & 1.555 & 3.66 \\
May & 0.69 & 1.58 & 1.488 & 3.67 \\
June & 0.61 & 1.94 & 1.588 & 3.05 \\
July & 0.61 & - & 1.669 & 3.89 \\
August & 0.66 & - & 1.597 & 3.50 \\
September & 0.63 & - & 1.751 & 3.38 \\
October & - & - & 1.613 & 2.68 \\
November & - & - & - & - \\
December & - & - & - & 4.53 \\
\hline
\end{tabular}

Table 6 presents the fifth-year energy consumption results at the study site. Energy consumption values range between 2.68 and $10.46 \mathrm{kWh} / \mathrm{t}$ per ton of aggregate with mean value $4.21 \mathrm{kWh} / \mathrm{t}$. Benchmarking analysis shows that crushers at other sites consumed between 0.61 and $1.94 \mathrm{kWh} / \mathrm{m}^{3}$ per ton of aggregate. Thus, energy consumption at the quarry under study was greater than at other sites. Therefore, Atabey aggregate quarry ceased production as non-economical 2 years after this study (Fig. 4).

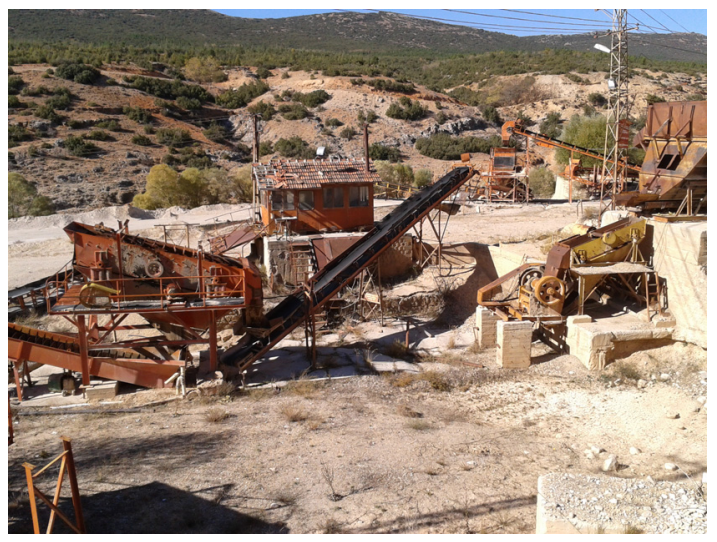

Figure 4. View of the quarry and production plant after the cease of production

\section{RESULTS AND DISCUSSION}

Geologic variability and differences were assessed in terms of plant equipment. Additionally, a detailed description of the grading conducted on site is provided. It was found that the less active production and processing period during the winter season consumed more electrical energy for production. This assessment was performed for $1002620 \mathrm{~m}^{3}$ of aggregates produced during a 5-year period with distinction in grading category. Energy consumption ratios for 5 years are presented, and its mean was calculated to be $4.44 \mathrm{kWh}$. The obtained results indicate that energy consumed during the 5 years lies within the interval between 2.46 and $17.79 \mathrm{kWh}$. However, the energy consumption rate was calculated as $3.14 \mathrm{kWh}$ during the experimental study at the site. This study shows that environmental load decrease can be assessed or investigated with respect to quarry processes as well as equipment age and use. From the foregoing, it is important for quarry operators to understand the factors that affect energy consumption to make rational decisions about the cost of running a quarry considering the cost of energy.

\section{CONCLUSIONS}

Aggregate quarry operations are energy intensive. A significant number of the facilities have older crushers with inefficient control, which calls for a significant research to increase production efficiency. The amount of energy consumed in the production of aggregate depends on the geological variability, homogeneity of gravels, grain size, scale of production, climatic conditions, equipment technology and maintenance, site organization and geography. Benchmarking analysis showed that energy consumption at the Atabey quarry was very high compared to other crushed rock producers 
in this region. According to the study made in the Atabey aggregate quarry, processing at the plant was not economical. Two years after the research, the production at the quarry was stopped.

\section{ACKNOWLEDGEMENTS}

The author wishes to thank the quarry owner, ATABETON Construction Ltd., engineers and technicians for assistance in experimental works and providing the necessary data.

\section{REFERENCES}

Awuah-Offei, K. (2016). Energy efficiency in mining: a review with emphasis on the role of operators in loading and hauling operations. Journal of Cleaner Production, (117), 89-97. https://doi.org/10.1016/j.jclepro.2016.01.035

Blachowski, J. (2013). Spatial analysis of the mining and transport of rock minerals (aggregates) in the context of regional development. Environmental Earth Sciences, 71(3), 1327-1338. https://doi.org/10.1007/s12665-013-2539-0

Erdoğan, M., Eren, R.H., \& Oktay, F.Y. (1999). Silivri çevresindeki Ergene formasyonunun agrega potansiyeli ve özellikleri. In Ulusal Kırmataş Sempozyumu' 99.

Faleschini, F., Zanini, M.A., Pellegrino, C., \& Pasinato, S. (2016). Sustainable management and supply of natural and recycled aggregates in a medium-size integrated plant. Waste Management, (49), 146-155.

https://doi.org/10.1016/j.wasman.2016.01.013

Galetakis, M., Zourbakis, V., Koinakis, I., Leventakis, K., \& Alevizos, G. (2013). Aggregate production on the Island of Crete, Greece: current production conditions and future perspective. Bulletin of the Geological Society of Greece, 47(4), 2030-2039. https://doi.org/10.12681/bgsg.11075

Gonçalves, J.P., Tavares, L.M., Toledo Filho, R.D., Fairbairn, E.M.R., \& Cunha, E.R. (2007). Comparison of natural and manufactured fine aggregates in cement mortars. Cement and Concrete Research, 37(6), 924-932. https://doi.org/10.1016/j.cemconres.2007.03.009

Guimaraes, M.S., Valdes, J.R., Palomino, A.M., \& Santamarina, J.C. (2007). Aggregate production: fines generation during rock crushing. International Journal of Mineral Processing, 81(4), 237-247. https://doi.org/10.1016/j.minpro.2006.08.004

Harthi, A.A., \& Abo Saada, Y.E. (1997). Wadi natural aggregates in Western Saudi Arabia for use in Concrete. Bulletin of the International Association of Engineering Geology, 55(1), 27-37. https://doi.org/10.1007/bf02635406

Ismail, S., Hoe, K.W., \& Ramli, M. (2013). Sustainable aggregates: the potential and challenge for natural resources con- servation. Procedia - Social and Behavioral Sciences, (101), 100-109. https://doi.org/10.1016/j.sbspro.2013.07.183

Jullien, A., Proust, C., Martaud, T., Rayssac, E., \& Ropert, C. (2012). Variability in the environmental impacts of aggregate production. Resources, Conservation and Recycling, (62), 1-13. https://doi.org/10.1016/j.resconrec.2012.02.002

Kaarsberg, T.M., HuangFu, E.P., \& Roop, J.M. (2007). Extreme energy efficiency in the U.S: industrial, economic and environmental impacts. In 2007 ACEEE Summer Study on Energy Efficiency in Industry (pp. 24-35). Washington, United States: American Council for an Energy-Efficient Economy.

Kecojevic, V., Vukotic, I., \& Komljenovic, D. (2014). Production, consumption and cost of energy for surface mining of bituminous coal. SME Mining Engineering, 66(1), 51-57.

KOSK (Kosk Enerji İnş. Taah. San. ve Tic. A.S.). (2014). Kırma-eleme tesisi ve dekoratif taş ocağl kapasite artışl raporu. Isparta: KOSK.

Levesque, M., Millar, D., \& Paraszczak, J. (2014). Energy and mining - the home truths. Journal of Cleaner Production, (84), 233-255. https://doi.org/10.1016/j.jclepro.2013.12.088

Menegaki, M.E., \& Kaliampakos, D.C. (2010). European aggregates production: drivers, correlations and trends. Resources Policy, 35(3), 235-244. https://doi.org/10.1016/j.resourpol.2010.01.003

NETAS (Netas Madencilik San. Tic. Ltd. Sti). (2015). Kırmaeleme tesisi ve kapasite artış proje raporu. Afyon: NETAS.

Pérez Fortes, A.P., Anastasio, S., Kuznetsova, E., \& Danielsen, S.W. (2016). Behaviour of crushed rock aggregates used in asphalt surface layer exposed to cold climate conditions. Environmental Earth Sciences, 75(21). https://doi.org/10.1007/s12665-016-6191-3

Rosado, L.P., Vitale, P., Penteado, C.S.G., \& Arena, U. (2017). Life cycle assessment of natural and mixed recycled aggregate production in Brazil. Journal of Cleaner Production, (151), 634-642. https://doi.org/10.1016/j.jclepro.2017.03.068

Scott, P.W., \& Harrison, D.J. (2008). Aggregate sources and supplies in Jamaica. Geological Journal, 43(5), 552-562. https://doi.org/10.1002/gj.1130

Tosun, A., \& Konak, G. (2014). Determination of specific charge minimizing total unit cost of open pit quarry blasting operations. Arabian Journal of Geosciences, 8(8), 6409-6423. https://doi.org/10.1007/s12517-014-1657-7

Wilburn, D.R., \& Goonan, T.G. (1998). Aggregates from natural and recycled sources; economic assessments for construction applications; a materials flow study. Circular, (1176), 1-31. https://doi.org/10.3133/cir1176

Yıldırım, M., \& Yılmaz, I. (2002). Yıldız Irmağı çökellerinin beton agregası olarak kullanılabilirliklerinin incelenmesi. Cumhuriyet Universitesi, Mühendislik Fakültesi Dergisi, Seri A, Yerbilimleri, 19(S2), 181-192.

\section{АНАЛІЗ СПОЖИВАННЯ ЕНЕРГІЇ ПРИ ПЕРЕРОБЦІ НЕРУДНИХ МАТЕРІАЛІВ (АТАБЕЙ, ІСПАРТА, ТУРЕЧЧИНА)}

\section{М. Озцелік}

Мета. Визначення витрат енергії та води в процесі виробництва нерудних матеріалів протягом тривалого проміжку часу шляхом обробки статистичних даних показників робочих процесів кар'єру й встановлення параметрів, що впливають на споживання енергії при переробці даної природної сировини.

Методика. В роботі використано та проаналізовано комплекс статистичних даних за енерговитратами і витратами води, а також виробничий цикл видобутку на кар'єрі Атабей за 5-річний період. Для оцінки величини енерговитрат також був проведений порівняльний аналіз за чотирма різними кар'єрами. 
Результати. Отримані результати аналізу показують, що енергія, споживана протягом 5 років, знаходиться в інтервалі між 2.46 і 17.79 кВт·год, яка в середньому становить 4.44 кВт·год. Однак під час проведення польових експериментальних досліджень цей показник склав 2.69 кВт·год. Встановлено, що протягом зимового періоду, коли знижується виробнича активність, переробні потужності споживають більше енергії, але менше води. Зроблено висновок щодо економічної нерентабельності підприємства з переробки нерудних матеріалів в кар'єрі Атабей. Виявлено, що найбільш значимими факторами, що впливають на кількість енергії, споживаної при виробництві будівельних матеріалів, є геологічна мінливість, однорідність гравію, розміру зерна, масштаб виробництва, кліматичні умови, технологія та технічне обслуговування обладнання, організація й географія майданчика.

Наукова новизна. Виявлено кореляційний взаємозв'язок споживаної енергії з обсягом виробництва будівельних матеріалів в умовах кар'єру Атабей, причому в зимовий період часу, коли знижуються темпи видобутку, споживання енергії по кар'єру істотно збільшується, а води - зменшується.

Практична значимість. В 2015 році, через два роки після завершення даного дослідження, виробництво нерудних матеріалів у кар'єрі Атабей було зупинене, що свідчить про достовірність отриманих результатів.

Ключові слова: енергія, енерговитрати, порівняльний аналіз, переробка нерудних матеріалів, кар'єр

\section{АНАЛИЗ ПОТРЕБЛЕНИЯ ЭНЕРГИИ ПРИ ПЕРЕРАБОТКЕ НЕРУДНЫХ МАТЕРИАЛОВ (АТАБЕЙ, ИСПАРТА, ТУРЦИЯ)}

\section{М. Озцелик}

Цель. Определение затрат энергии и воды в процессе производства нерудных материалов в течение длительного периода времени посредством обработки статистических данных показателей рабочих процессов карьера, а также установление параметров, влияющих на потребление энергии при переработке данного природного сырья.

Методика. В работе использован и проанализирован комплекс статистических данных по энергозатратам и расходу воды, а также производственный цикл добычи на карьере Атабей за 5-летний период. Для оценки величины энергозатрат также был проведен сравнительный анализ по четырем различным карьерам.

Результаты. Полученные результаты анализа показывают, что энергия, потребляемая в течение 5 лет, находится в интервале между 2.46 и 17.79 кВт·ч, которая в среднем составляет 4.44 кВт·ч. Однако во время проведения полевых экспериментальных исследований этот показатель составил 2.69 кВт·ч. Установлено, что в течение зимнего периода, когда снижается производственная активность, перерабатывающие мощности потребляют больше энергии, но меньше воды. Сделаны вывод об экономической нерентабельности предприятия по переработке нерудных материалов в карьере Атабей. Выявлено, что наиболее значимыми факторами, влияющими на количество энергии, потребляемой при производстве строительных материалов, является геологическая изменчивость, однородность гравия, размера зерна, масштаб производства, климатические условия, технология и техническое обслуживание оборудования, организация и география площадки.

Научная новизна. Выявлена корреляционная взаимосвязь потребляемой энергии с объемом производства строительных материалов в условиях карьера Атабей, причем в зимний период времени, когда снижаются темпы добычи, потребление энергии по карьеру существенно увеличивается, а воды - снижается.

Практическая значимость. В 2015 году, через два года после завершения данного исследования, производство нерудных материалов в карьере Атабей было остановлено, что свидетельствует о достоверности полученных результатов.

Ключевые слова: энергия, энергозатраты, сравнительный анализ, переработка нерудных материалов, карьер

\section{ARTICLE INFO}

Received: 22 March 2018

Accepted: 9 September 2018

Available online: 17 September 2018

\section{ABOUT AUTHORS}

Mehmet Ozcelik, Doctor of Philosophy, Associate Professor of the Department of Geological Engineering, Süleyman Demirel University, Batı Campus, 32260, Isparta, Turkey. E-mail: ozcelikmehmet@sdu.edu.tr 